\title{
An Implementation of Customer Relationship Management and Customer satisfaction in Banking Sector of Quetta, Balochistan
}

\author{
Sadaf Ajmal ${ }^{1}$, Sana-Ur-Rehman ${ }^{2}$ \\ ${ }^{1}$ Institute of Management Sciences (IMS), University of Balochistan, Quetta, Pakistan \\ ${ }^{2}$ NFC-Institute of Engineering and Technology, Multan, Pakistan \\ Correspondence: Sadaf Ajmal, Institute of Management Sciences (IMS), University of Balochistan, Quetta, \\ Pakistan.
}

Received: August 22, 2019

Accepted: September 9, 2019

Online Published: September 16, 2019

doi:10.5539/ibr.v12n10p26

URL: https://doi.org/10.5539/ibr.v12n10p26

\begin{abstract}
Banking industry in Pakistan has become highly competitive, bankers are putting enhanced efforts to acquire and retain customers by incorporating innovative customer relationship management (CRM) techniques. Due to rapid technology penetration, customers have rapid entrance and options to multiple financial products/services. Present study focuses on measuring customer satisfaction in the result of Bank's CRM efforts. Research is based on the fact and evolve the theme of the study, that is to find the significant factors affect customer satisfaction, that is a center of customer relationship management (CRM) for controlling the excessive competition in Quetta banking industry. Two structured questionnaires are used based on quantitative view and hand out on a stratified sample. First questionnaire is having a data of 31 employees in the sampled banks to measure the CRM suitability while second one is having a data of 302 customers from the sampled banks to count the level of customer satisfaction. The findings show that the selected banks apply the CRM components and found that these are positively associated with customer satisfaction. Respecting the results of the bank survey, the level of CRM implementation and the relevance of its elements be unlikely from one to another bank. Findings confirm that in Quetta banking sector there is a tough competition going on as every bank (public, private) is trying its best to capture more and more customers. Banks have to bring change in their strategies to build and strengthen relationship with their customers because it is one of the major competitive advantages.
\end{abstract}

Keywords: CRM, customer satisfaction, KM, KCF

\section{Introduction}

In today's dramatically changing environment, organizations are realizing the importance of understanding customers' behaviors, needs and wants. Through the effective use of communication, technology and information organizations are offering customer's bunch of products with competitive prices and services to cultivate their loyalty. Financial service sector is using assets based on customer's span of knowledge, in order to retain existing customers who are the great source of profitability, and to attract the new customers. The basic premise upon which CRM rests is that enhancing the customer's experiences and understanding customer needs is the key to customer retention, organization profitability and growth. Current and prospective customers are important to a business as to retain one existing customer is 5 to 6 times more cost effective than attracting one new customer (Abubakae \& Mukhtar, 2015).

CRM has become highly modernize process and tool for the companies to retain customers. To facilitate the customers and to meet market competition, CRM is a novel way to understand needs and desires of customers. Successful CRM is achieved through innovative use of organization's actions, people, business, process, and technology (Agarwal, 2009).

CRM in banking sector increases customer value by using some analytical and the traditional models. For economic significance, banks play a great role, as intermediaries, in mobilizing public savings and funds for the productive purposes (Chaudhary \& Sharma, 2011). Customer Satisfaction is based on the organization critical service attributes particularly in pre, during and post service delivery. These attributes are encounter by customers and its end result on satisfaction on the level of services obtained. It is essential to practice excellent service strategically for customer satisfaction, which contributes a lot to the bottom line of the organizations 
(Lonial \& Raju, 2015). CRM increases the performance of the organizations through identifying, acquiring, building and maintain best relationship with their customers (Haghshenas \& Ahmadi, 2015).

To identify banks most profitable customers CRM sounds most effective strategy. Banks have to establish CRM strategy and carefully implement it for gaining a competitive advantage. Interaction with client's increases company profitability and consumer satisfaction. Therefore, assessing CRM practices of private and public banks are a prerequisite to know the wants and needs of customers as well as for the success of the banking industry. Different types of CRM activities are already being used in banks, some as operational CRM and some as communicational CRM. Globalization has made increasingly difficult for banks to meet the high growth of customer expectations. Banking competition is increasing year by year to gain a greater slice of market share. Banks are looking ways of achieving growth through acquisition of new customers and retaining existing ones. Customer satisfaction in banking industry mostly revolves around the service, which includes service quality, level of access, service characteristics, and complain handling system of the customers. Managing and creating a customers' database, training of employees, reducing waiting time of the customers, employees recognition on customer services through rewarding will result in best customer satisfaction. Implementing and effective CRM system will automatically result in higher customer satisfaction (Rostami et al., 2014). The objective of the research study is to see the impact of CRM on customer satisfaction.

\section{Theoretical Background}

CRM, being an associative field, execute areas like marketing, management and information system (Kevork \& Vrechopoulos, 2009). Rigo et al., (2016), Adikram (2016) \& Wali et al., (2015) define CRM as "Customer Satisfaction attitude towards a service provider, or an emotional reaction to the difference between what customers anticipate and what they receive, regarding the fulfillment of some needs, goals or desires". CRM strategy connects three fundamental dimensions of an organization that are strategy, philosophy and technology. The success of CRM strategy depends on the right balance between three important organizational resources i.e. process, people and technology. With these three resources, organizations are able to use CRM to achieve high levels of customer satisfaction, retention and loyalty (Rigo et al., 2016, Manzuma-Ndaaba, et al., 2016). CRM is "A comprehensive strategy and process that enables an organization to identify, acquire, retain and nurture profitable customers by building and maintaining long-term relationships with them" (Adikram, 2016, Oluseye et al., 2014, Wahab et al., 2011).

In today's competitive economy, many organizations are realizing the importance of customers, and are of the view that CRM should be a core to all business strategies (Wu, 2008). Kincaid (2003) describe CRM as "the strategic use of information, processes, technology, and people to manage the relationship with customers across the whole customer cycle. According to Lun \& Yingying (2008) "CRM is the philosophy, policy and coordinating strategy mediated by a set of information technologies, which focuses on creating two way communication with customers so that firms have an intimate knowledge of their needs, wants, and buying patterns".

$\mathrm{Ku}$ (2010) points out that "CRM provides analytical, operational, and directional capabilities. The analytical capabilities enhance profitability maximization from the customer relationship, operational capabilities cut across the customer value process, and directional capabilities depend on strategic skills and reflect the sharpness of long term cooperation and organizational values". According to Saeed Awadh bin-Nashwan and Haslinda Hassan (2017) insurance companies, banks, and service providers are now know the importance of CRM in capturing new customers, retaining existing ones and maximizing their life time vale.

This paper elaborates CRM as a compound construct based on four behavioral elements such as Key customer focus, Organizing CRM, Knowledge Management and Technology.

\section{Customer Relationship Management Construct}

Sin et al., (2010) is of the view that CRM is a multi-dimensional construct consisting of four broad behavioral components: key customer focus, organizing CRM, knowledge management, and technology-based CRM.

\subsection{Focusing Key Customers}

Due to the increased global competition, organizations identified the importance and necessity to become customer-centric. Organizations need CRM as a key competitive strategy in order to stay focused on the needs of their customers, to coordinate a customer centric approach throughout the organization (Zadeh et al., 2012). Organization key to success depends on managing the relationship between organizations and its current key customers (Gebert et al., 2002). 


\subsection{Organizing CRM}

Organizing CRM is an essential mean by which firms assemble business activity for employees and customers (Sin et al., 2005; Yim et al., 2005). Organizations develop an appropriate working environment, adding staff with modern technologies, sound reward system, management systems for customer satisfaction, and motivational leadership to conduct customer-oriented behaviors and to enhance service employees (Mechinda \& Patterson, 2011). Upcoming marketing settlements like brand differentiation, distribution, price and communication may influence by a certain organization of CRM (Richards \& Jones, 2008).

\subsection{Knowledge Management}

Organizations performance depends on building better relationship with their customers and managing knowledge effectively. Proper interactions with the customers through different touch points effectively transform customer information into knowledge. Fan and Ku (2010) are of the view that customer knowledge management enables firms to get hold strategic managerial commitments to refine an ongoing execution and associated with market capabilities.

\subsection{Technology}

Collecting and analyzing data on customer's patterns, developing prediction models, effective customized communications, timely response, and efficient way of delivering personalized offerings to the individual customers; all such CRM applications take great advantage from technology (Peppard 2000; Vrechopoulos 2004). Technology regarding CRM helps companies in improving communication, sales presentations, tailor communication through collecting, analyzing and distributing information, and facilitates the companies for cross-referencing the customers between different parts of firms for more sales options (Widmier et al., 2002). With the help of database marketing, data mining, data warehousing, and push technologies banking industry is striving to incorporate the latest technologies to their CRM system.

\section{Customer Satisfaction}

Enhanced Customer satisfaction is very important for getting intended results from different CRM practices in banking industry. CRM induced Customer satisfaction has gained increased attention from the researchers and practitioners alike as one of the recognized field of scholarly study and used as a fundamental tool by financial institutions for enhancing organizational performance and profitability. Sugiati et al., (2013) elaborate customer satisfaction as "feeling of a customer after comparing performance (outcome) to the expectation related to the aspects that are offered".

Customer satisfaction is "the extent to which a product's perceived performance in delivering value matches a buyer's expectations" (Armstrong \& Kotler, 2003).

CRM is a philosophy that places the customer at the heart of a business organization's processes, culture and activities to improve customer's satisfaction of services, and maximizes the profits for the organizations (Agarwal, 2009). According to Basuroy et al., (2014) customer satisfaction is an investment, which is considered as an intangible asset to the organizational balance sheet. CEOs wealth on long-term incentives compensation and firm stock prices increases when the customers are satisfied with the products and services offered by the organization. Customer satisfaction forms the mutually beneficial relationships between customers and banks. According to Chopra et al., (2012), customers are becoming individualistic, quality conscious and impulsive in their buying behaviors that demands a complete range of products and services in order to optimize their products and services. Customers confidence can be increased towards services when the satisfied, a satisfied customer can uplift the frequency of their visits as well as new to bank numbers increases (Wu. $\mathrm{Li}, \& \mathrm{Li}, 2018$ ).

\subsection{Antecedents of Customer Satisfaction in Banking Industry}

\subsubsection{Bank Personnel}

Personnel are the key pillar of any organization whether small or large and have a vital contribution to the success of building a company's sustainable position. Characteristics concerning personnel are responsiveness, skills and knowledge, collaboration, communication and friendliness with customers. If the bank personnel are responsive to their duty, have a friendly attitude, communicate properly with the customers, handle any issue or problem relating to services, and have skill and knowledge then the customers are not just satisfied but a major source of profit to the banks for the long run.

\subsubsection{Service Quality}

Service quality is considered as an important measure of customer satisfaction. According to Parasuraman et al., (1988), service quality is described as "A global judgment or attitude, relating to the superiority of the service". 
Service Quality comes first. If quality of the service delivered to customers is superb, customer may neglect every other issue related with the product/services. Hokanson (1995) pointed out that in Pakistani banking sector, banks service quality is efficient having speedy transaction system, confidentiality, accuracy of the billing, billing timelines, and friendly personnel behavior; satisfied the customers. Service quality is considered as crucial part in organization execution and ill service quality creates a bad brand image in the eyes of customers that is then difficult to remove. According to Chekalina et al., (2018) organizations by maintaining and building a strong service quality can provide a high value to their customers.

Service quality is a critical component in any company's performance. Bad service creates a lousy brand image in the eyes of customers, which is difficult to remove. Service quality does not only give assurance of new customers, but it also helps the organizations to earn a sustainable long-term competitive advantage which is an ultimate source of customer satisfaction. (Muhammad Farooq et al., 2019).

\subsubsection{Bank Access}

Access is defined as a mean of approach or entering into a place, permission or the right to enter, make use of something, get near, or to have a contact with someone. Network expansion, branches location, as well as observed troubles in the service system like strikes, damaged ATMs, etc are included (Mihelis et al., 2011). Customer satisfaction is considered an outcome of bank access. If bank access system is proper, customers are satisfied automatically because of the access to the services and use of it.

\section{CRM and Customer Satisfaction}

As discussed earlier, implementation of CRM successfully offers many advantages to organizations as better sells; customer satisfaction, service cost, time, lessen delicacy, market share profitability because it has emerged in recent era as a strategic solution to business problems.

Payne \& Frow (2005) declers that CRM contains the enhancement and creation based on individual customer relationship targeting group of customers evolve in widening customers' value. An application of CRM requires the organizations to identify their own profitable customers and to provide them personalized services in order to increase and enhance customer satisfaction in the end. Small or large organizations have to choose CRM for maintain relationship with new to organization or existing customers for increasing profitability. CRM is its long-term focus, in which a product or service provider takes the time to really understand the needs of individual customers, and to develop personalized offerings that reflect the customer's needs for enhancing the level of customer satisfaction. Linda L. (Lillard \& Mohammed Nasser Al-Suqri, 2018). Many advantages could be gained when implementing CRM such as organizational benefits in terms of customer satisfaction and customer loyalty. (Ahmed Al-Arafati et al., 2019)

\section{Conceptual Framework and Hypothesis}

Having conceptual coherence to the CRM area by inquiring the aspects of successful CRM implementation, current research focuses to desired results of having a CRM orientation within the organization.

Customer satisfaction is a successful tool for marketing. Successful CRM implementation requires a company-wide key customer focus in one-to-one marketing efforts to fully understand their wants and needs on an ongoing basis (Sheth et al., 2000). With Bank-wide understanding and internal support for key customer, the customers are satisfied, and influenced thus, it is proposed that:

$\mathrm{H}_{1}$ : Key customer focus is positively related with customer satisfaction.

Banks must maintain valuable relationships with a strong focus on key customers in its CRM system. Banks assure that they can enhance customer relationship and satisfy customer's needs. Stefanou et al., (2003) are of the view that successful CRM must focus on customer satisfaction by continuously focusing on customers' needs and wants. A study on the long-term customer relationship with their bank and the level of satisfaction by Molina et al., (2007) reveals that bank's ensure customers to have a significant effect on customer satisfaction.

$\mathrm{H}_{2}$ : The CRM organization is positively related with customer satisfaction.

Literature reveals that managing knowledge is a cornerstone to apply CRM, which depends on creating; transferring knowledge to better meets expectations of customer. According to Alemu Muleta Kebed \& Zewdu Lake Tegegne (2018), there is a positive relationship between CRM organization and bank performance as the customer satisfaction is the key indicator to performance.

$\mathrm{H}_{3}$ : The knowledge management is positively related with customer satisfaction.

Banks structure could be made customer centric having use of knowledge and CRM - based technology. An 
organization can provide customized offerings to its value customers by using technology. Ultimately boosting customer satisfaction. Incorporating CRM technology enhances customer satisfaction, more profitable customer relationship and higher customer retention (Butler, 2000).

$\mathrm{H}_{4}$ : The technology is positively related with customer satisfaction.

Implementation of CRM successfully having advantages to organizations as better sales; customer satisfaction, service cost: time resulting in lessen down customer switching. Implementation of CRM has emerged in recent era as a suspension to business issues.

$\mathrm{H}_{5}$ : The CRM is positively related with customer satisfaction.

The research work concluded that KCF, CRM organization, Knowledge Management and Technology-based CRM predicted the bank performance. This means that these variables were predictors of bank performance, which in one or another way depends on the level of customer satisfaction (Alemu Muleta Kebed \& Zewdu Lake Tegegne, 2018).

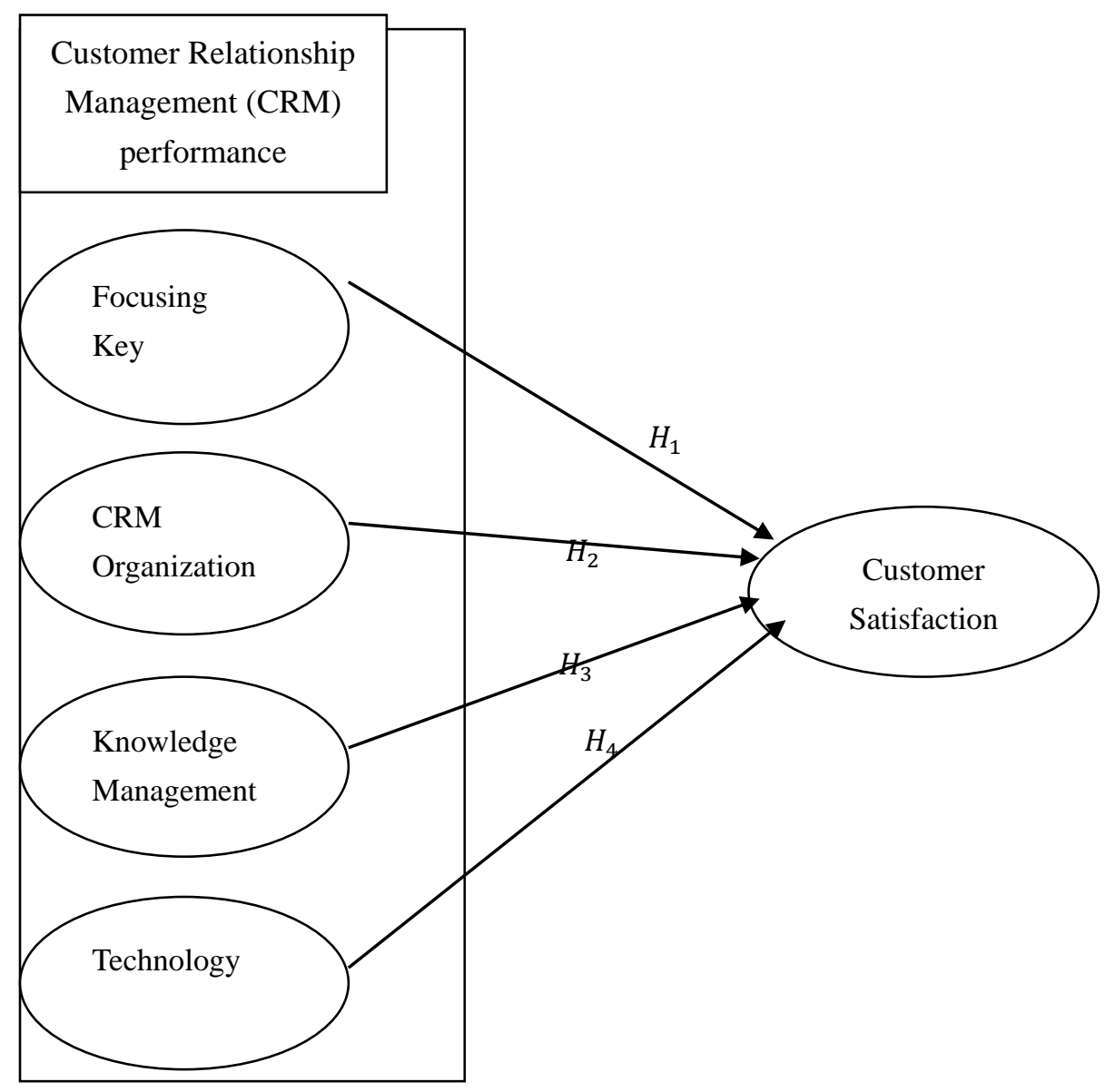

Figure 1. Conceptual model of CRM and customer satisfaction

\section{Methodology}

The study used convinces sampling technique to reach bank managers and respective branch clients. Keeping in mind sample size criteria developed by Hill \& Alexander (2000), 40 managers were approached from the chosen banks resulting in 31 responses from 31 branches out of 39 branches of public and private banks in Quetta city. As well as based on the number of branches of particular banks selected in Quetta city 400 customers were approached resulting in 302 responses, one hundred fifty one responses from the public and one hundred fifty one responses from the private bank. Two chosen banks have large market share and network of branches in Pakistan. In different cities of Balochistan especially in Quetta city these banks are providing people benefits of employment, finance, training and economic development. 
Questionnaire is adapted from the literature as an instrument for data collection from both customers and managers. A five-point Likert scale from strongly disagrees with value 1 to strongly agree with value 5 is used. Twenty-one items for the measurement of CRM are adapted from Churchill, (1979); Gerbing \& Anderson, (1988); Kohli \& Jaworski, (1990); Desphande et al., (1993); Diamantopoulos \& winklhofer, (2001); Chong \& Rundus, (2004); Sin et al., (2005); and Das et al., (2009). Twenty-five items for the measurement of customer satisfaction are adapted from Hayes, (1992); Heskett et al, (1994); Schneider \& Bowen, (1995). Customer satisfaction as a construct is measured through three-sub variable known as Bank personals, service quality and bank access.

\section{Analysis}

Construct validity of latent variables is tested by exploratory factor analysis (Field, 2009). Rotated component matrix for CRM and customer satisfaction is given in Table 1 and 2, which shows that all the items of CRM and customer satisfaction construct are loaded properly given their eigenvalues and percentage of variance.

Table 1. Rotated component Matrix for CRM

\begin{tabular}{|c|c|c|c|c|}
\hline Items & KCF & $\begin{array}{l}\text { Organizing } \\
\text { CRM }\end{array}$ & KM & Technology \\
\hline My bank provides customized services and products to our key customers. & .943 & & & \\
\hline My bank work constantly to delight our key customers. & .946 & & & \\
\hline staff in my bank treats key customers with much care. & .933 & & & \\
\hline My bank makes an effort to find out what our key customer needs. & .931 & & & \\
\hline Customers feedback on delivery and quality. & .913 & & & \\
\hline We systematically manage the expectations of high value customers. & .813 & & & \\
\hline $\begin{array}{l}\text { We recognize that some customers are short term oriented while others are } \\
\text { long term oriented }\end{array}$ & .828 & & & \\
\hline We focus on close contact with our customers. & .731 & & & \\
\hline $\begin{array}{l}\text { Customer-centric performance standards are established and monitored at all } \\
\text { customer touch points. }\end{array}$ & & .778 & & \\
\hline $\begin{array}{l}\text { Employee performance is measured and rewarded based on meeting customer } \\
\text { needs and successfully serving them. }\end{array}$ & & .775 & & \\
\hline We have a proper complaint management system. & & .796 & & \\
\hline We reply customer feedback quickly. & & & .795 & \\
\hline $\begin{array}{l}\text { Our organization fully understands the needs of our key customers through } \\
\text { their feedback. }\end{array}$ & & & .884 & \\
\hline $\begin{array}{l}\text { We use information from customers to design or improve our products or } \\
\text { services }\end{array}$ & & & .907 & \\
\hline $\begin{array}{l}\text { We have an effective customer recovery strategy including guarantees for } \\
\text { service failures. }\end{array}$ & & & .885 & \\
\hline We have a right software to serve our customers & & & & .902 \\
\hline $\begin{array}{l}\text { We have right technical personnel to provide technical support for the } \\
\text { utilization of computer technology in building customer relationships. }\end{array}$ & & & & .905 \\
\hline Individual customer information is available at every contact point & & & & .948 \\
\hline We maintain a comprehensive database of our customers & & & & .810 \\
\hline We continually update our software programs. & & & & .704 \\
\hline We communicate with our customers through e-mail, phone, Fax and web. & & & & .665 \\
\hline Eigenvalue & 7.43 & 3.61 & 3.26 & 2.70 \\
\hline Percentage of variance & 29.7 & 14.4 & 13.0 & 10.7 \\
\hline
\end{tabular}


Table 2. Rotated component matrix for customer satisfaction

\begin{tabular}{|c|c|c|c|}
\hline Variable's Item & $\begin{array}{l}\text { Bank } \\
\text { personal }\end{array}$ & $\begin{array}{l}\text { Service } \\
\text { quality }\end{array}$ & $\begin{array}{l}\text { Bank } \\
\text { access }\end{array}$ \\
\hline Knowledge and skills of my bank staff is perfect. & .617 & & \\
\hline I am very satisfied from the responses of my bank staff. & .648 & & \\
\hline I have a friendly relationship with my bank staff. & 659 & & \\
\hline Bank staff always understands and satisfy my financial needs. & .643 & & \\
\hline My bank staff always does the right things at the first time. & 690 & & \\
\hline Bank staff is never busy to response my request. & .669 & & \\
\hline Staff of my bank always follow their promises & .679 & & \\
\hline Staff of my bank properly handles any problem that arises. & .676 & & \\
\hline Staff of my bank has the ability to answer all my questions. & .695 & & \\
\hline \multicolumn{4}{|l|}{ My bank staff is } \\
\hline Friendly. & .776 & & \\
\hline Willing to help. & .811 & & \\
\hline Having a concerned and caring attitude. & .796 & & \\
\hline Providing prompt customer service. & .772 & & \\
\hline Being capable and competent. & .702 & & \\
\hline Giving me their undivided attention. & .755 & & \\
\hline Being consistently courteous. & .679 & & \\
\hline Maintaining a professional appearance. & .505 & & \\
\hline Bank statements are easy to read and understandable. & & .532 & \\
\hline My bank always provides error free statements. & & .601 & \\
\hline My bank maintains clean and pleasant branch office facilities. & & .654 & \\
\hline My bank charges reasonable service fees. & & .615 & \\
\hline My bank charges competitive interests rates on loans. & & .554 & \\
\hline My bank provides me with a good value in banking products and services. & & .499 & \\
\hline The branch network of my bank is much expanded. & & & 615 \\
\hline I have never been in trouble due to ATM machines of my bank. & & & .567 \\
\hline Eigenvalue & 9.27 & 3.24 & 1.48 \\
\hline Percentage of variance & 37.03 & 12.96 & 5.91 \\
\hline
\end{tabular}

One of the most frequent reliability measures used by the researchers for measuring the items' internal consistency is Cronbach alpha (Gebeyehe Jalu, 2014). For each of the four dimensions of CRM and three dimensions of customer satisfaction Cronbach's alpha values are in appropriate range as shown in Table 3. Reliability coefficients for all variables exceed 0.7 as recommended by Nunnally, 1978; Shifera, 2011).

Table 3. Scale reliabilities for CRM and customer satisfaction

\begin{tabular}{lcc}
\hline & No of items & $\boldsymbol{\alpha}$ \\
\hline KCF & 08 & .981 \\
Organizing CRM & 03 & .863 \\
KM & 04 & .907 \\
Technology & 06 & .955 \\
Bank personnel & 17 & .938 \\
Service quality & 06 & .894 \\
Bank access & 02 & .710 \\
\hline
\end{tabular}

Table 4. Correlation Matrix b/w Dependent and Independent Variables

\begin{tabular}{lllll}
\hline & \multicolumn{3}{c}{ Overall } \\
\hline 1.KCF & 1. & 2. & 3. & 4. \\
2.CRM organization & 1 & & & \\
3.KM & $.309^{*}$ & 1 & & \\
4. Technology & .196 & .275 & 1 & \\
5.Customer satisfaction & $.416^{*}$ & $.552^{* *}$ & .270 & 1 \\
\end{tabular}

${ }^{*} \mathrm{P}<.05, \quad * * \mathrm{p}<0.01$

Table 4 indicates, results of correlation analysis among dependent (customer satisfaction) and independent variables (KCF, CRM organization, KM, and technology). Simultaneously correlation analysis results indicate that all independent variables $\mathrm{KCF}, \mathrm{CRM}$ organization, KM, and technology have a significant impact on customer satisfaction. 
Regression analysis is applied to test the dependency between independent and dependent variables. Three-hundred and two customers and thirty-one managers. One fifty-one customers each from public sector bank and one fifty-one customers of private sector bank responded. From fifteen branches of public sector bank data is being collected and from sixteen branches of private sector bank. Every single manager of both sector banks has some customers from which data is collected. For regression, analysis data of dependent variables is equated by taking average values of all customers associated with respective bank manager/officer.

Table 6. Regression Analysis

\begin{tabular}{|c|c|c|c|c|c|}
\hline & \multicolumn{5}{|c|}{ Beta } \\
\hline KCF & $\begin{array}{l}.451^{* * *} \\
(2.72)\end{array}$ & & & & $\begin{array}{l}.171 \\
(1.24)\end{array}$ \\
\hline CRM organization & & $\begin{array}{l}.662^{* *} \\
(4.76)\end{array}$ & & & $\begin{array}{l}.388^{* * *} \\
(2.52)\end{array}$ \\
\hline KM & & & $\begin{array}{l}.412^{*} \\
(2.44)\end{array}$ & & $\begin{array}{l}.194 \\
(1.48)\end{array}$ \\
\hline Technology & & & & $\begin{array}{l}.630^{* *} \\
(4.37)\end{array}$ & $\begin{array}{l}.295^{*} \\
(1.86)\end{array}$ \\
\hline $\mathbf{R}^{2}$ & .225 & .439 & .170 & .397 & .595 \\
\hline Adj $R^{2}$ & .198 & .430 & .141 & .376 & .532 \\
\hline
\end{tabular}

* $\mathrm{P}<.05, \quad * * \mathrm{p}<0.01$, parentheses ( ) shows the t-value. Dependent variable (customer satisfaction)

As first hypothesis states that key customer focus is positively related with customer satisfaction. According to Table 6 , key customer focus is positively related with customer satisfaction $(\beta=.451, \mathrm{t}=2.72, \mathrm{p}<0.01)$. Moreover, key customer focus accounts for an explaining significant amount of variation in customer satisfaction $\left(\mathrm{R}^{2}=.225\right.$, $\operatorname{adj} \mathrm{R}^{2}=.198$ ). It proves that organization success depends upon managing the relationship between its current key customers. As KCF, increases from the management side the level of customer satisfaction increases too. KC are the main element of any firm success of failure study reveals that as more the attention is paid to the key organization customers the more satisfied they are.

Our second hypothesis state that's organizing CRM is positively related with customer satisfaction. Table 6 shows, there is a significant impact of organizing CRM on customer satisfaction $(\beta=.662, t=4.76, p<0.01)$. CRM organization accounts for a significant amount of variation in customer satisfaction $\left(R^{2}=.439\right.$, adj $\left.R^{2}=.430\right)$. Its proves that organizing CRM activities (i.e. having good working environment, appropriate reward system, inspirational leadership to enhance service employees to conduct customer oriented behaviors, and providing staff with modern tools and technology) are the essential mean through which firms organize their actual business processes for employees and customers, and by improving these activities has a greater impact on customer satisfaction.

Our third hypothesis state that knowledge management is positively related with customer satisfaction. According to the Table 6, there is a relationship between $\mathrm{KM}$ and customer satisfaction, $\mathrm{KM}$ is positively related with customer satisfaction $(\beta=.412, \mathrm{t}=2.44, \mathrm{p}<0.05)$. However, KM accounts for a significant amount of variation in customer satisfaction $\left(\mathrm{R}^{2}=.170\right.$, adj $\left.\mathrm{R}^{2}=.141\right)$. It proves that customer knowledge management enables the organizations to take strategic managerial decisions for improving the ongoing performance and to keep the customers satisfy. Proper management of knowledge helps keeping the customer satisfied and if the existing ones are satisfied new can also be caught.

Forth hypothesis States that technology is positively related with customer satisfaction. According to the results as shown in Table 6 , there is a significant relationship between technology and customer satisfaction $(\beta=.630, t=$ $4.37, \mathrm{p}<0.01)$. Moreover, technology accounts for a significant amount of variation in customer satisfaction $\left(\mathrm{R}^{2}=.397\right.$, adj $\left.\mathrm{R}^{2}=.376\right)$. It proves that incorporating CRM technology enhances customer satisfaction. Technology regarding CRM helps companies to improve communication with their customers, and tailored communication through collecting, analysis and distributing information.

Simple linear regression proves that KCF, CRM organization, KM, and technology have a significant impact on customer satisfaction. As, management focuses on the CRM activities increases it increases level of customer satisfaction.

According to the Fifth hypothesis, CRM has positive impact on customer satisfaction. Multiple regression analysis shows the simultaneous positive effect of all CSR component on Customer satisfaction as key customer focus $(\beta=.151, \mathrm{t}=1.06, \mathrm{p}>0.05)$ Organizing $\operatorname{CRM}(\beta=.388, \mathrm{t}=2.52, \mathrm{p}<0.01) \mathrm{KM}(\beta=.194, \mathrm{t}=1.48, \mathrm{p}>0.05)$ 
technology $(\beta=.295, \mathrm{t}=1.86, \mathrm{p}<0.05)$ accounts for a significant amount of variation in customer satisfaction $\left(\mathrm{R}^{2}=.595\right.$, adj $\left.\mathrm{R}^{2}=.532\right)$ hence proving $\mathrm{H} 5$.

\section{Discussion}

Customers are the basis for maintaining a competitive edge; the more strong the relations of banks with their customers are, higher the chance of their success. Building and strengthening a relationship with the customers is essential. According to Gilbert (2003), it is difficult for the competitors if banks build and maintain a strong relationship with their customers because building and maintain a close and satisfactory relationship with customers is of much importance for any organization. Major focus of CRM in banks is just not to acquire new customers but also to build a higher level of customer satisfaction in existing ones and to make them loyal too. The best weapon of banking institutions with in a strong competitive environment is to establish and maintain customer focus attitude with the implementation of CRM activities. All over the world, banking sector is facing immense competition, and Pakistani-banking sector is not an exception. While following the fact that acquiring new customer is more costly than retaining the existing ones researcher developed the basic purpose of this research study that is to discover the major factors that affect the customer satisfaction, which is a focus of CRM for overcoming high competition in banking sector of Quetta ,Balochistan.

The Pakistani banking industry has chosen the CRM activities, as being fully aware about better use of resources for maintaining products and services, and the need to maintain customer's base to satisfy them more and more.

This research study helps the banks to build a level of customer satisfaction, which is a major focus of CRM. The CRM practices construct is empirically tested and found an increase in organizational performance in terms of customer satisfaction. The analysis of results shows that the four dimensions of CRM practices - KCF, organizing CRM, KM, and technology are the important element in increasing customer satisfaction. The more the customers are satisfied the more banks focus on implementing CRM practices. According to the management and customer survey CRM, elements are having positive impact on customer satisfaction. According to figure 1, conceptual model of CRM and customer satisfaction the affect of studied factors on customer satisfaction and their affect on each other vary from bank to bank and this variation can help the banks to understand their weakness, in order to build and strengthen satisfaction of their customers.

\section{Limitations}

This study is limited to the basic purpose of this research study, to discover the major factors that affect customer satisfaction, which is a focus of CRM for overcoming high competition in the banking sector of Quetta, Balochistan. Based on the sampling criteria, researcher examines two categories of banks in Quetta, serving as a public bank and private bank. This research study is limited to Quetta because of researcher's costs, time and other constrains.

\section{References}

Abubakar, M., \& Mukhtar, S. (2015). Relationship Marketing, Long Term Orientation and Customer Loyalty in Higher Education. Mediterranean Journal of Social Sciences, 6(4), 466-474. https://doi.org/10.5901/mjss.2015.v6n4p466

Adamantios, D., \& Heidi, M. W. (2001). Index construction with formative indicators: An alternative to scale development. Journal of marketing research, 38(2), 269-277. https://doi.org/10.1509/jmkr.38.2.269.18845

Adikaram, C. H. (2016). The Relationship between Customer Relationship Management and Customer Satisfaction. International Journal of Arts and Commerce, 5(2), 69-95.

Agarwal, R. (2009). A comparative study of nationalized and private banks with reference to customer relation management. School of management studies Punjab University, Patiala.

Ahmed Al-Arafati., K. A. K., \& Sami, A. (2019). The mediating effect of output quality on the relationship between top management support and customer satisfaction on the implementation of customer relationship management system in public sector. Academy of Strategic Management Journal, 18(2).

Alemu, M. K., \& Zewdu, L. T. (2018). The effect of customer relationship management on bank performance: In context of commercial banks in Amhara Region, Ethiopia. Business \& Management, 5, 1499183. https://doi.org/10.1080/23311975.2018.1499183

Armstrong, G., \& Philip, K. (2003). Marketing: An Introduction Upper Saddle River, NJ. 5th (Ed.): Prentice Hall. 
Basuroy, S., Gleason, K. C., \& Kannan, Y. H. (2014). CEO compensation, customer satisfaction, and firm value. Review of Accounting and Finance, 13(4), 326-352. https://doi.org/10.1108/RAF-11-2012-0120

Butler, S. (2000). Changing the game: CRM in the e-world. Journal of Business Strategy, 21(2), 13-14. https://doi.org/10.1108/eb040067

Chaudhary, K., \& Sharma, M. (2011). Performance of Indian public sector banks and private sector banks: A comparative study. International journal of innovation, management and technology, 2(3).

Chekalina, T., Fuchs, M., \& Lexhagen, M. (2018). Customer based destination brand equity modeling: The role of destination resoueces, value for money, and vale issue. Journal of Travel Research, 57(1), 31-51. https://doi.org/10.1177/0047287516680774

Chong., \& Rundus. (2004). Total quality management, market competition and organizational performance. The British accounting review, 36(2), 155-172. https://doi.org/10.1016/j.bar.2003.10.006

Chopra, A., Arora, U., \& Kumar, R. (2012). An empirical study on customer perception towards CRM practices in foreign banks", IJMRS's international journal of management science, $1(2)$.

Churchill, G. A. (1979). A paradigm for developing better measures of marketing constructs. Journal of marketing research, 16(1), 64-73. https://doi.org/10.1177/002224377901600110

Deshpandé, R., Farley, J. U., \& Webster, F. E. (1993). Corporate Culture, Customer Orientation, \& Innovativeness in Japanese Firms: A Quadrad Analysis. Journal of Marketing, 57(1), 23-37. https://doi.org/10.1177/002224299305700102

Fan, Y., \& Ku, E. (2010). Customer focus, service process fit and customer relationship management profitability: the effect of knowledge sharing. The Service Industries Journal, 30(2), 203-222. https://doi.org/10.1080/02642060802120141

Field, A. (2009). Discovering statistics using SPSS: and sex and drugs and rock n'roll (3 ed.): sage publications.

Gebert, H., Geib, M., Kolbe, L., \& Riempp, G. (2002). Towards customer knowledge management: Integrating customer relationship management \& knowledge management concepts. Paper presented at the Second International Conference on Electronic Business, Taipei, Taiwan.

Gebeyehe, J. (2014). Effects of customer relationship management on market performance: the case of selected. Journal of marketing management, Mekelle city.

Gerbing, D. W., \& James, C. A. (1988). An Updated Paradigm for Scale Development Incorporating Unidimensionality and Its Assessment. Journal of Marketing Research, 25(2), 186-192. https://doi.org/10.1177/002224378802500207

Haghshenas, M., \& Ahmadi, S. M. (2015). The effects of customer relationship management dimensions on organizational performance Case study: shipping organization of Iran. WALIA journal, 31(4), 134-141.

Hayes, S. C. (1992). Verbal relations, time, and suicide Reno, NV: Context Press in S. C. Hayes \& L. J. Hayes (Eds.). Understanding verbal relations, 109-118.

Heskett, J. L., Jones, T. O., Loveman, G. W., Sasser., W. E., \& Schlesinger, L. A. (1994). Putting the service-profit chain to work. Harvard Business Review, 72(2), 164-174.

Hokanson, S. (1995). The deeper you analyze the more you satisfy customers: Marketing News, 16.

Jagdish, N. S., Rajendra, S. S., \& Arun, S. (2000).The antecedents and consequences of customer-centric marketing. Journal of academy of marketing science, 28(1), 55-66. https://doi.org/10.1177/0092070300281006

Jun, W. (2008). Customer relationship management in practice: A case study of Hi-tech company from China. Service Systems and Service Management, International Conference, Sch. of Econ and Manage. Beijing Univ. of Posts \& Telecommunication. https://doi.org/10.1109/ICSSSM.2008.4598558

Kevork, E. K., \& Vrechopoulos, A. P. (2009). CRM literature: conceptual \& functional insights by keyword analysis. Journal of marketing intelligence \& planning, 27(1), 48-85. https://doi.org/10.1108/02634500910928362

Kincaid, J. W. (2003). Customer relationship management: Getting it Right, Prentice Hall, Upper Saddle River, NJ.

Kohli, A. K., \& Bernard, J. J. (1990). Market orientation: The construct, research propositions, and managerial 
implications. Journal of marketing, 54(4), 1-18. https://doi.org/10.1177/002224299005400201

$\mathrm{Ku}, \mathrm{C}$. S. E. (2010). The impact of customer relationship management through implementation of information systems. Journal of Total Quality Management, 21(11), 1085-1102. https://doi.org/10.1080/14783360903250514

Langerak, F., \& Peter, C. V. (2003). Strategically Embedding CRM. Business Strategy Review, 14(4), 73-80. https://doi.org/10.1111/j..2003.00289.x

Linda, L. L., \& Mohammed, N A. (2018). Librarians Learning from the Retail Sector: Reaching Out to Online Learners Using Customer Relationship Management. Journal of Arts and Social Sciences, 9(3), 15-26. https://doi.org/10.24200/jass.vol9iss3pp15-26

Lonial, S., \& Raju, P. S. (2015). Impact of service attributes on customer satisfaction and loyalty in a healthcare context. Leadership in Health Services, 28(2), 149-166. https://doi.org/10.1108/LHS-12-2013-0045

Lun, Z., Li, J. L., \& Wang, Y. Y. (2008). Customer relationship management system framework design of Beijing rural commercial bank. In IEEE international conference on service operations \& logistics and informatics, 97-101.

Manzuma-Ndaaba, N., Harada, Y., Romle, A., \& Shamsudin, A. (2016). Cognitive, Affective and Conative Loyalty in Higher Education Marketing: Proposed Model for Emerging Destinations. International Review of Management and Marketing, 6(S4), 168-175.

Mechinda, P., \& Patterson, P. G. (2011). The impact of service climate \& service provider personality on employees' customer-oriented behavior in a high-contact setting. Journal of Services Marketing, 25(2), 101-113. https://doi.org/10.1108/08876041111119822

Mihelis, G., Grigoroudis, E., Siskos, Y., Politis., Y., \& Malandrakis, Y. (2011). Customer satisfaction measurement in banks private banking sector. Commercial Bank of Greece.

Molina, A., Martin, C., David, E., \& Agueda. (2007). Relational benefits and customer satisfaction in retail banking, Emerald. https://doi.org/10.1108/02652320710754033

Muhammad, F., Saeed, M., Valliappan, R. K., Ramanathan, K., \& Abdul, Q. (2019). Measuring and Comparing the Desired and Actual Service Quality of Pakistan International Airline. The Journal of Social Sciences Research, 5(2), 484-490. https://doi.org/10.32861/jssr.52.484.490

Nunnally, J. C. (1978). Psychometric Theory, New York: McGraw-Hill.

Oluseye, O., Tairat, T., \& Emmanuel, O. (2014). Customer Relationship Management Approach and Student Satisfaction in Higher Education Marketing. Journal of Competitiveness, 6(3), 49-62. https://doi.org/10.7441/joc.2014.03.04

Parasuraman, A., Zeithalm, V., \& Berry, L. (1988). A multiple item scale for measuring consumers perceptions of service quality. Retailing, 12-40.

Payne, A., \& Frow, P. (2005). The role of multichannel integration in customer relationship management. Industrial Marketing Management, 33(6). https://doi.org/10.1016/j.indmarman.2004.02.002

Peppard, J. (2000). Customer relationship management (CRM) in financial services. European management journal, 18(3), 312-327. https://doi.org/10.1016/S0263-2373(00)00013-X

Richards, K. A., \& Jones, E. (2008). Customer relationship management: finding value drivers. Industrial Marketing Management, 37(2), 120-130. https://doi.org/10.1016/j.indmarman.2006.08.005

Rigo, G., Pedron, C., Caldeira, M., \& Araújo, C. (2016). CRM Adoption in a Higher Education Institution. Journal of Information Systems and Technology Management, 13(1), 45-60. https://doi.org/10.4301/S1807-17752016000100003

Rostami, A. R., Valmohammadi, C., \& Yousefpoor, J. (2014). The relationship between customer satisfaction and customer relationship management system; a case study of Ghavamin Bank. Industrial and Commercial Training, 46(4), 220-227. https://doi.org/10.1108/ICT-10-2013-0067

Saeed, A. B., \& Haslinda, H. (2017). Impact of customer relationship management (CRM) on customer satisfaction and loyalty: A systematic review. Issue (1), 86-107

Schneider, B., \& Bowen, D. E. (1995). Winning the Service Game. Boston, MA: Harvard Business School Press.

Shifera, B. (2011). The Impact of Relationship Marketing on Customer Loyalty (The Case of Bank of Abyssinia). 
Master's Thesis, Addis Abeba University, Addis Abeba.

Sin, L. Y. M., Tse, A. C. B., \& Yim, F. H. K. (2005). CRM: conceptualization and scale development. European Journal of Marketing, 39(11/12), 1264-1290. https://doi.org/10.1108/03090560510623253

Stefanou, C., Christos, S., \& Amalia, S. (2003). CRM and customer-centric knowledge management: An Empirical Research. Business Process Management Journal, 9(5), 617-634. https://doi.org/10.1108/14637150310496721

Sugiati, T., Thoyib, A., Hadiwidjoyo, D., \& Setiawan, M. (2013).The Role of Customer Value on Satisfaction and Loyalty (Study on Hypermart's Customers). International Journal of Business and Management Invention, 2, 65-70.

Swarnamoni, D., \& Gayatri, S. (2009). Antidiabetic Action of Ethanolic Extracts of Punica granatum Linn: In Alloxan-induced Diabetic Albino Rats. Stamford journal of pharmaceutical sciences, 2(1), 14-21. https://doi.org/10.3329/sjps.v2i1.5810

Vrechopoulos, A. P. (2004). Mass customization challenges in internet retailing through information management. International journal of information management, 24, 59-71. https://doi.org/10.1016/j.ijinfomgt.2003.09.013

Wahab, S., Jusoff, K. A., K., Noor, N., \& Zahari, A. (2011). The influence of usability and enjoyment on electronic customer relationship management performance in Jordan mobile communication services. Journal of Business Management, 5(1), 128-134.

Wali, F., Wright, T., Nwokah, G., \& Reynolds, L. (2015). Customer Relationship Management and Service Quality: a qualitative study. European Academy of Management (EURAM) Conference, 17th - 20th June, 2015, Kozminski University, Warsaw.

Widmier, S. M., Donald, W. J., \& Deborah, B. M. (2002). Infusing technology into personal selling. Journal of personal selling \& sales management, 22(3), 189-198.

Wu, H. C., Li, M. Y., \& Li, T. (2018). A study of experiential quality, experiential value, experiential satisfaction, theme park image, and revisit intention. Journal of Hospitality \& Tourism Research (Washington, D.C.). 42(1), 26-73. https://doi.org/10.1177/1096348014563396

Yim, F. H., Anderson, R. E., \& Swami, N. S. (2005). Customer relationship management: Its dimensions and effect on customer outcomes. Journal of personal selling \& Sales Management, 24(4), 265-280.

Zadeh, A. H. T., \& Jafari, H. S. (2012). Studying CRM maturity in service organizations in Isfahan province case study: Sina hospital. Interdisciplinary journal of contemporary research in business, 3(9), 273-280.

\section{Copyrights}

Copyright for this article is retained by the author(s), with first publication rights granted to the journal.

This is an open-access article distributed under the terms and conditions of the Creative Commons Attribution license (http://creativecommons.org/licenses/by/4.0/). 